\title{
Music in the relief of stress and distress in cancer patients
}

\author{
Música no alívio do estresse e distress de pacientes com câncer \\ Música para aliviar el estrés y angustia de los pacientes con cáncer
}

Mariana Scheidegger dos Santos' ORCID: 0000-0002-5694-1622

Filipe de Moraes Thomaz" ORCID: 0000-0003-4654-1075

Rafael Tavares Jomar'I' ORCID: 0000-0002-4101-7138

Angela Maria Mendes Abreu'v ORCID: 0000-0002-7894-4242

Gunnar Glauco De Cunto Carelli Taetsv ORCID: 0000-0003-4427-7864

'Antônio Cândido de Camargo Cancer Center. São Paulo, São Paulo, Brazil. "Faculdade de Medicina de Campos. Campos dos Goytacazes, Rio de Janeiro, Brazil.

IIIInstituto Nacional de Câncer José Alencar Gomes da Silva. Rio de Janeiro, Rio de Janeiro, Brazil. "Universidade Federal do Rio de Janeiro. Rio de Janeiro, Rio de Janeiro, Brazil. vUniversidade Federal do Rio de Janeiro. Macaé, Rio de Janeiro, Brazil.

How to cite this article: Santos MS, Thomaz FM, Jomar RT, Abreu AMM, Taets GGCC. Music in the relief of stress and distress in cancer patients. Rev Bras Enferm. 2021;74(2):e20190838. https://doi.org/10.1590/0034-7167-2019-0838

Corresponding author: Gunnar Glauco De Cunto Carelli Taets E-mail: masterufrj@gmail.com

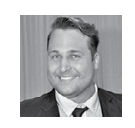

EDITOR IN CHIEF: Antonio José de Almeida Filho ASSOCIATE EDITOR: Hugo Fernandes

Submission: $08-10-2020$

Approval: 11-26-2020

\begin{abstract}
Objectives: to evaluate the effects of music on the physiological stress and distress of cancer patients being treated in a hospital. Methods: quasi-experimental study carried out with cancer patients hospitalized in the nursing wards of a public hospital. There was a single 15-minute intervention using music. It was individual, and headphones were used for patients to listen to three songs chosen by each one. The levels of stress and distress were measured before and after the intervention, using music to analyze the cortisol in the saliva and the answers to the distress thermometer. The significance level of the statistical analysis was $5 \%$, using the non-parametric Wilcoxon test. Results: the mean age of the 26 patients was 56 years old. Most were female, white, and had breast cancer. After intervention, there were statistically significant diminutions in both stress and distress $-p<0.001$. Conclusions: the use of music diminishes the stress and the distress of cancer patients.

Descriptors: Nursing; Music; Neoplasms; Physiological Stress; Psychological Stress.
\end{abstract}

\section{RESUMO}

Objetivos: avaliar o efeito da música sobre estresse fisiológico e distress de pacientes com câncer em tratamento em ambiente hospitalar. Métodos: estudo quase-experimental realizado com pacientes com câncer internados em enfermarias de um hospital público. A intervenção única com música durou 15 minutos e ocorreu individualmente usando fones de ouvido em três músicas escolhidas pelos pacientes. $O$ estresse e o distress foram mensurados antes e depois da intervenção com música mediante análise do cortisol salivar e das respostas ao termômetro de distress. A análise estatística adotou nível de significância de $5 \%$ aplicando-se o teste não paramétrico de Wilcoxon. Resultados: a idade média dos 26 pacientes foi de 56 anos. A maioria: sexo feminino, cor branca e com câncer de mama. Após a intervenção, houve redução estatisticamente significante no estresse e no distress $-p<$ 0,001 . Conclusões: o uso da música reduziu o estresse e o distress de pacientes com câncer. Descritores: Enfermagem; Música; Neoplasias; Estresse Fisiológico; Estresse Psicológico.

\section{RESUMEN}

Objetivos: evaluar efecto de la música sobre estrés fisiológico y angustia de pacientes con cáncer en tratamiento en ambiente hospitalario. Métodos: estudio cuasiexperimental realizado con pacientes con cáncer internados en enfermerías de un hospital público. Intervención única con música duró 15 minutos y ocurrió individualmente usando auriculares en tres músicas elegidas por los pacientes. El estrés y la angustia mensurados antes y después de la intervención con música mediante análisis del cortisol salival y de respuestas al termómetro de angustia. Análisis estadístico adoptó nivel de significación de $5 \%$ aplicándose el test no paramétrico de Wilcoxon. Resultados: edad mediana de los 26 pacientes fue de 56 años. La mayoría: sexo femenino, color blanca y con cáncer de mama. Tras la intervención, hubo reducción estadísticamente significante en el estrés y en la angustia $-p<0,001$. Conclusiones: el uso de la música redujo el estrés y la angustia de pacientes con cáncer.

Descriptores: Enfermería; Música; Neoplasias; Estrés Fisiológico; Estrés Psicológico. 


\section{INTRODUCTION}

The first use of music in health, as a form of care and humane treatment, was reported in 1859 by Florence Nightingale and, later, by Isa Maud Ilsen and Harriet Seymour, and its first actual uses in hospitals were in the first years of the 20th century. It was not only used in psychiatry, but also to diminish the surgical pain of soldiers who had been wounded in World War I and II(1).

In nursing, music is applied as a complementary way to reduce pain, promote wellbeing, and relief other nursing diagnoses, such as: spiritual anguish, sleep disturbances, despair, risk for loneliness, social isolation, and stress. This is because music promotes positive physiological effects, such as changes in arterial pressure, cardiac and respiratory frequency, and diminution of pain stimuli(2).

A review of the state of the art about the use of music in cancer nursing was carried out including all articles published in the last ten years, in the databases PubMed, LILACS, and BDENF, using the descriptors for "Music", "Nursing", "Cancer", and the boolean connector AND, from November 2018 to July 2019. It was found that the use of music by oncology nursing is connected to the possibility of generating biological, psychological, social and spiritual effects, also showing itself as an action that can raise awareness for a sensible health care ${ }^{(1)}$.

Other publications suggested that the use of music, as a therapy for women with breast cancer, has an effect in diminishing stress and anxiety ${ }^{(3-4)}$. No experimental studies were found that used music in oncology nursing, which is an important gap in knowledge that justifies the need to carry out this study.

A high number of cancer patients respond to the disease and/ or to its treatment not only with physical symptoms, but also with a diminution in their functioning, loss of a job or leave from work, social isolation, fear, sadness, anger, anxiety, depression, and uncertainties that lead to emotional suffering ${ }^{(5-7)}$.

In 1997, the National Comprehensive Cancer Network ${ }^{(8)}$ and the American Psychosocial Oncology Society ${ }^{(9)}$ determined that the word "distress" should be used to refer to the psychological stress and/or to the emotional suffering experienced by the cancer patient, since this term adequately characterizes the psychosocial aspects of cancer treatment. This suffering can be measured through a self-report.

The term distress can be defined as "an unpleasant and multifactorial emotional experience, of a psychological (cognitive, behavioral, and emotional), social, or spiritual nature, which interferes in the ability to effectively deal with cancer, its physical alterations, symptoms, and treatment ${ }^{\prime \prime(8-9)}$.

Physiological stress, on the other hand, can be defined as "a complex response from the organism, that involves physical, psychological, mental, and hormonal reactions when confronted with any event interpreted by the person as challenging ${ }^{\prime \prime(10)}$. Therefore, it is "a response from the organism to a stimulus, mediated by the interpretation it is given, according to which this stimulus, interpreted as challenging, causes a break in the homeostasis of the internal functioning, which, in turn, triggers a need to adapt to preserve wellbeing and life"(10).
Considering the above, the following research question was determined: Can music relief the physiological stress and the distress of cancer patients being treated in a hospital environment?

\section{OBJECTIVES}

To evaluate the effects of music on the physiological stress and distress of cancer patients being treated in a hospital.

\section{METHODS}

\section{Ethical aspects}

This study was approved by the Research Ethics Committee of the Universidade Federal do Rio de Janeiro, in the Campus of the city of Macaé, respecting the requirements of Research Ethics Committee of the National Council of Health.

\section{Design, period, and place of study}

This is a quasi-experimental study, of the before/after time, carried out from January to July 2018, in a public hospital in the city of Macaé, RJ, Brazil. This is a medium sized hospital, with 150 beds, which attends all medical specialties, including cancer outpatient treatment and hospitalization. The design of the study followed the recommendations from the Standard Protocol Items: Recommendations for Interventional Trials (SPIRIT) ${ }^{(11)}$.

\section{Population, sample, criteria of inclusion and exclusion}

The population of the study was made up by 29 adult patients diagnosed with cancer and hospitalized in the nursing wards of the hospital that served as setting for this study, from January to February 2018. All patients addressed by the researches accepted participating in the study. Three of these patients were not feeling well and, for that reason, refused participating in the intervention. The sample, by convenience, included 26 patients, who were in accordance with the following inclusion criteria: being 18 years old or older, having at least one medical cancer diagnosis, being under treatment in the hospital setting of the study. The exclusion criteria were: being deaf or having auditory deficiency and using corticosteroids before the music intervention; doses that varied from 1 to $3 \mathrm{mg} / \mathrm{kg} /$ day were considered to be high doses with the potential to be immunosuppressive ${ }^{(12)}$.

\section{Study protocol}

The single intervention with music took place individually. Patients chose whether to lay down or sit in their beds in the nursing wards of the hospital setting of the study, and the music was played through earphones; the session lasted for about 15 minutes, and each patient listened to three songs chosen by themselves. Researches decided not to choose which songs would be played, thus allowing the patient to take the main role in making decisions about their health/disease, and believing that the songs that are likely to contribute for better therapeutic 
results are the ones chosen by the patient. The musical styles chosen the most by participants were: religious music, Brazilian popular music, and international pop music.

It stands out that this study chose to carry out only one intervention because it aimed to evaluate the immediate effect of using music over stress and distress. The 15-minute duration was chosen based on previous studies that used music as a therapeutic intervention ${ }^{(13-16)}$.

To evaluate physiological stress, cortisol was used as a biomarker, since it is the main glucocorticoid released by the adrenal cortex when in a stressful situation. It has been considered to be the stress hormone, since its production and secretion increase during and after the exposure to certain stressing factors ${ }^{(17-20)}$. This hormone, which can be easily detected in saliva, in addition to being an important measuring variable, is an effective, accessible, fast, and non-invasive measurement method.

To evaluate it, two adequately trained researches collected the saliva of the cancer patients immediately before and after the music intervention, using a cotton swab that was maintained from one-to-two minutes under the tongue. Later, the swab, identified with the number of the subject, was stored in a thermal box to be taken to the lab, where it was adequately stored for later cortisol analyses ${ }^{(17)}$. The amount of cortisol in the saliva samples was assessed through an electrochemiluminescence immunoassay, and the reference values for cortisol adopted by the lab that analyzed the saliva samples was $<0.736$ $\mu \mathrm{g} / \mathrm{dL}$, corresponding to the values that are normally found from $10 \mathrm{~h}$ to $16 \mathrm{~h}$, which is the period in which the samples were collected.

To evaluate distress, the distress thermometer was used, which allows the patient to sign their distress levels, from 0 (no distress) to 10 (extreme distress) ${ }^{(21)}$.

The researchers also collected, in the record of the patients, their sociodemographic data, including: age, sex, self-reported skin color, educational level, marital status, religion, and city of origin.

\section{Analysis of results and statistics}

Data analysis was carried out, at first, submitting patients to the exploratory statistic technique with the distribution of simple frequencies to describe the population studied. Later, the means of salivary cortisol and distress, before and after intervention, were evaluated, using the Wilcoxon test. The analyses were carried out in the software Graph Pad Prisma 7, and the significance level adopted was $p<0.05$.

\section{RESULTS}

The mean age of the 26 patients of the study was $56( \pm 17)$ years old; their other sociodemographic characteristics are in Table 1.

The subjects of the study presented 11 types of neoplasms, according to Figure 1.

After the intervention, there was a statistically significant reduction in the levels of salivary cortisol $(p<0.0001)$ and in distress levels $(p<0.0001)$ (Table 2; Figures 2 and 3 ).
Table 1 - Sociodemographic characteristics of the subjects of the study, Macaé, Rio de Janeiro, Brazil, 2018

\begin{tabular}{lcc}
\hline Characteristics & $\mathbf{n}$ & $\%$ \\
\hline Sex & & \\
$\quad$ Female & 19 & 73.1 \\
Male & 07 & 26.9 \\
Skin color & & \\
White & 20 & 76.9 \\
Brown & 04 & 15.4 \\
Black & 02 & 7.7 \\
Years of formal education & & \\
Incomplete elementary school & 11 & 42.3 \\
Incomplete high school & 12 & 46.3 \\
Complete high school & 02 & 7.7 \\
Incomplete higher education & 01 & 3.8 \\
Religion & & \\
$\quad$ Catholic & 11 & 42.3 \\
Evangelical & 11 & 42.3 \\
Buddhist & 03 & 3.8 \\
No religion & 01 & 11.5 \\
\hline
\end{tabular}

Table 2 - Means and standard deviations of the physiological stress and distress levels, before and after intervention, Macaé, Rio de Janeiro, Brazil, 2018

\begin{tabular}{lcccccc}
\hline & \multicolumn{2}{c}{$\begin{array}{c}\text { Physiological stress } \\
\text { (cortisol, } \boldsymbol{\mu g} / \mathbf{d L})\end{array}$} & & Distress & \\
& Mean & $\begin{array}{c}\text { Standard } \\
\text { deviation }\end{array}$ & $\begin{array}{c}\boldsymbol{p} \\
\text { value }\end{array}$ & Mean & $\begin{array}{c}\text { Standard } \\
\text { deviation }\end{array}$ & $\begin{array}{c}\boldsymbol{p} \\
\text { value }\end{array}$ \\
\hline Before & 0.17 & 0.41 & $<$ & 4.00 & 3.02 & $<\mathbf{0 . 0 0 0 1}$ \\
After & 0.15 & 0.35 & $<001$ & 3.00 & 1.48 & \\
\hline
\end{tabular}

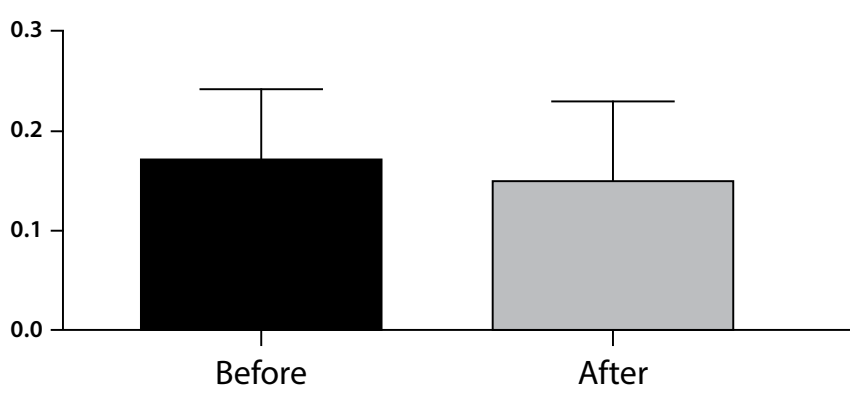

Figure 2 - Means of the salivary cortisol $(\mu \mathrm{g} / \mathrm{dL})$ levels before and after the intervention, Macaé, Rio de Janeiro, Brazil, 2018 


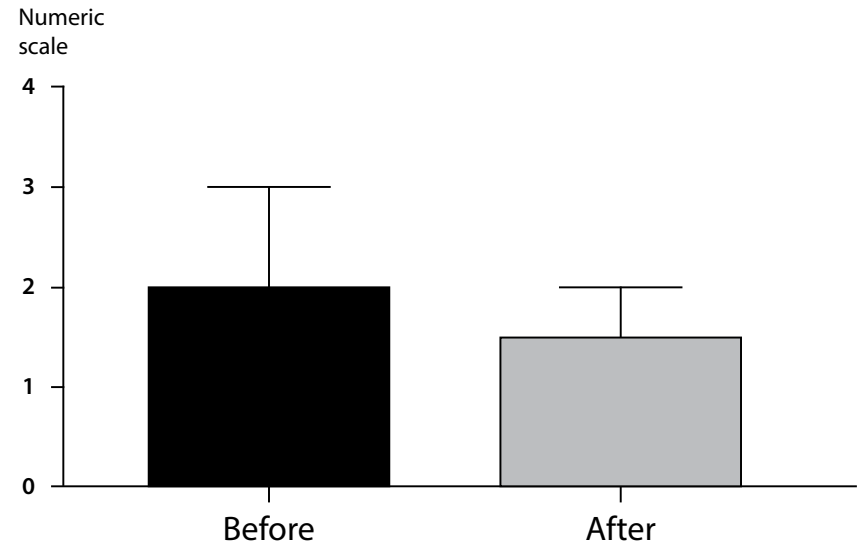

Figure 3 - Means of the distress levels before and after the intervention, Macaé, Rio de Janeiro, Brazil, 2018

\section{DISCUSSION}

This study used a biochemical stress marker: the salivary cortisol. To the knowledge of its authors, this is the first experimental study in Brazilian literature that uses a biomarker to evaluate the effects of music on the stress and the distress of cancer patients undergoing treatment in a hospital environment

There was a significant statistical diminution in the mean of salivary cortisol after 15 minutes of music intervention, suggesting that this type of care is effective in the treatment of cancer patients, with regard to several stressing situations that originate from the treatment of the disease itself.

Most patients in the study were females (73\%) and had breast cancer (42.3\%). This malady is relevant worldwide, since it is the main cause of cancer and the main cause of cancer deaths among women in Brazil and in the world ${ }^{(22)}$. Cancer treatment can involve hospitalization, an excessive number of exams, complex chemotherapy schemes, complex names of medications, collateral effects, among others, which can bring to the patient feelings of fear, anguish, pain, and lead to excessive emotional efforts, leading the cancer patient to develop stress ${ }^{(23)}$.

Studies have shown the impacts of stress in cancer patients: a North-American research, for instance, showed that stress contributes for the tumor angiogenesis, studied using as a model a rat with orthotopic ovary cancer, in which the chronic stress induced in daily periods led to higher levels of catecholamines, a higher tumor load, and a more invasive pattern to the disease ${ }^{(24)}$. Another study, also from the United States, used results of patients with metastatic breast cancer, showing flat or abnormal daytime rhythms of cortisol, associated with an earlier mortality of patients ${ }^{(25)}$.

The intervention using music is an alternative for care, to be applied by oncology nurses to delay stressing factors. Using no more than an earphone and a cellphone, one can bring, to the person who listens to the song, a moment in which they can meet themselves. As the listener chooses their song and close their eyes, they are transported to a private universe, in which they can imagine themselves free from the disease and out of the often hostile nursing ward environment - a place which may be permeated by pain and suffering, signaling distance from family and from home. The song chosen by the patient can bring back the life that was left out of the hospital.

A revision study states that music interventions are capable of producing many therapeutic effects, such as reducing pain, stress and anxiety, promoting comfort, muscle relaxation, among others $^{(26)}$. The person in a stressful situation, such as the treatment of a cancer, seeks support in coping mechanisms such as their family, beliefs, or in the listing of songs that sooth them ${ }^{(27)}$.

In turn, the distress that affects cancer patients has been considered the sixth vital sign, and must be recognized, monitored, recorded, and treated in all stages of the disease ${ }^{(1)}$.

Some studies use other strategies that involve not only music to diminish the distress of cancer patients. That is the case of a North-American systematic review ${ }^{(4)}$, which informs that interventions such as meditation, stress management (through techniques of guided imagination, relaxation, and counseling) and yoga are recommended to diminish anxiety and even depression.

One of the researches also highlighted that more than $70 \%$ of participants were described by their relatives as having clinical level distress $(\geq 4)$, a prevalence that is much higher than the one indicated by studies with patients who self-evaluated their distress, among whom the frequency was that of $30 \%$ and $50 \%{ }^{(7)}$.

A practical implication, based on the results found in this study, about the theme of physiological stress and/or distress of cancer patients, is the adoption of actions that use music from a preventive perspective, preventing stress from ever reaching high levels. Stress can trigger a series of diseases if nothing is done to minimize tension, with the possibility of leading to depression or even to acute problems, such as heart attacks and strokes even though stress does not cause these diseases, it can trigger the diseases to which the person is predisposed ${ }^{(28)}$.

Therefore, in this study, important aspects were shown with regard to the use of music as a therapeutic resource to reduce physiological stress and distress, since it is a non-invasive method that can be understood as a light care technology, with benefits for such an important goal as the reduction of stress, considering the potential stressing situations that arise during the cancer treatment. Furthermore, the importance of looking beyond physical stress is reiterated, meaning that the emotional stress of the cancer patient also needs to be identified and treated, so the person can be integrally cared for.

Music, seen as a light technology, uses attributes from human relations that are essential to build bonds in the spaces of hospital care, which was also true for this research. Music can also be seen as "an innovative care technology, when organized as an activity that is simultaneously systematic and creative, since it facilitates the expression of emotion, interpersonal communication, and the possibility of therapeutic effects"(29).

\section{Study limitations}

This study has limitations, including the fact that the sample is small and by convenience, which prevented an analysis of the effect of music on the physiological stress and distress of patients with cancer that considered the influence of other variables, such as sex, age, educational level. Therefore, new experimental 
studies are suggested to be carried out, to evaluate the effects of music over stress sand distress throughout the treatment of cancer patients, as well as the potential change in its effect when other variables are considered.

\section{Contributions to the Field of Nursing and Health}

This study brings two contributions, not only for health, but to all health professionals who care for cancer patients. The first is related to the choice of a method that is not commonly used in nursing studies, especially when one intends to guarantee that an intervention is scientific - the musical intervention - , making it possible to measure biological alterations. The second is related to the fact that we found a small number of studies that have this theme as their study subject, meaning that it becomes extremely relevant to study the effects of the use of music in cancer patients, to broaden the possibilities of caring for this type of patient and promote a non-invasive and non-pharmacological form of treatment, which, still, is capable of acting on the physical and emotional needs of the patients.

\section{CONCLUSIONS}

This study showed evidence that the use of music with patients being treated for cancer was capable of diminishing their stress and distress.

\section{REFERENCES}

1. Santos MS, Taets GGCC. A importância do uso da música pela enfermagem em oncologia. Enferm Bras. 2020;19(1):87-95. https://doi. org/10.33233/eb.v19i1.3057

2. Silva ACP, Oliveira ML, Carvalho LC, Lima CC. Efeitos da música clássica aplicada em crianças hospitalizadas. REAS/EJCH. 2020;(48):e3215. https://doi.org/10.25258/reas.e3215.2020

3. Greenlee H, DuPont-Reyes MJ, Balneaves LG, Carlson LE, Cohen MR, et al. Clinical practice guidelines on the evidence-based use of integrative therapies during and after breast cancer treatment. CA Cancer J Clin 2017;67(3):194-232. https://doi.org/10.3322/caac.21397

4. Kang Duck-Hee, Traci M, Yeonok S. Changes in complementary and alternative medicine use across cancer treatment and relationship to stress, mood, and quality of life. J Altern Complem Med 2014;20(11):853-9. https://doi.org/10.1089/acm.2014.0216

5. Arab C, Correia CK, Demonico BB, Vilarino GT, Andrade A. Câncer de mama e reações emocionais: revisão sistemática. Rev Baiana Saúde Pública. 2016;40(4):968-90. https://doi.org/10.22278/2318-2660.2016.v40.n4.a1679

6. Vale CCSO, Dias IC, Miranda KM. Câncer de mama: a repercussão da mastectomia no psiquismo da mulher. Mental [Internet]. 2017 [cited 2020 Jun 09];1 1(21):527-45. Available from: http://pepsic.bvsalud.org/scielo.php?script=sci_arttext\&pid=S167944272017000200014\&lng=pt\&tlng=pt

7. Andrade AMR, Azevedo JMH. O impacto do diagnóstico oncológico: contribuições da terapia cognitivo-comportamental. Rev Científ HSI [Internet]. 2018 [cited 2020 Jun 09];2(2):36-40. Available from: https://revistacientifica.hospitalsantaizabel.org.br/index.php/RCHSI/article/ view/109/91

8. National Comprehensive Cancer Network. NCCN Clinical Practice Guidelines in Oncology (NCCN Guidelines ${ }^{\oplus}$ ):distress Management. NCCN [Internet]. 2018 [cited 09 Jun 20]. Available from: https://oncolife.com.ua/doc/nccn/Distress_Management.pdf

9. Strain JJ, Loigman M. Quick reference for oncology clinicians: the psychiatric and psychological dimensions of cancer symptom management. Psychooncol. 2007;16(5):502-3. https://doi.org/10.1002/pon.1143

10. Malagris LEN, Fiorito ACC. Avaliação do nível de stress de técnicos da área de saúde. Estud Psicol (Campinas). 2006 [cited 2019 Jun 29];23(4):391-8. https://doi.org/10.1590/S0103-166X2006000400007

11. Chan AW, Tetzlaff JM, Altman DG, Laupacis A, Gøtzsche PC, Krleža-Jeric' K, et al. Declaración SPIRIT 2013: definición de los elementos estándares del protocolo de un ensayo clínico. Rev Panam Salud Publica [Internet]. 2015 [cited 2020 Sep 26];38(6):506-14. Available from: https://www.scielosp.org/pdf/rpsp/2015.v38n6/506-514/en

12. Finamor LP, Finamor JF, Muccioli C. Corticoterapia e Uveítes. Arq Bras Oftalmol. 2002; 65(4):483-6. https://doi.org/10.1590/ S0004-27492002000400018

13. Chen LC, Wang TF, Shih YN, Wu LJ. Fifteen-minute music intervention reduces pre-radiotherapy anxiety in oncology patients. Eur J Oncol Nurs. 2013;17(4):436-41. https://doi.org/10.1016/j.ejon.2012.11.002

14. McClurkin SL, Smith CD. The Duration of Self-Selected Music Needed to Reduce Preoperative Anxiety. J PeriAnesthesia Nurs. 2016;31(3):196208. https://doi.org/10.1016/j.jopan.2014.05.017

15. Sim CS, Sung JH, Cheon SH, Lee JM, Lee JW, Lee J. The effects of different noise types on heart rate variability in men. Yonsei Med J. 2015;56(1):235-243. https://doi.org/10.3349/ymj.2015.56.1.235

16. Chiu-Hsiang L, Chien-Ying L, Ming-Yi H, Chiung-Ling L, Yi-Hui S, Chung-Ying L, et al. Effects of music intervention on state anxiety and physiological indices in patients undergoing mechanical ventilation in the intensive care unit: a randomized controlled trial. Biol Res Nurs. 2017;19(2):137-44. https://doi.org/10.1177/1099800416669601

17. Martínez-Miró S, Tecles F, Ramón M, Escribano D, Hernández F, Madrid J, et al. Causes, consequences and biomarkers of stress in swine: an update. BMC Vet Res. 2016;12(171). https://doi.org/10.1186/s12917-016-0791-8 
18. Keremi B, Beck A, Fabian TK, Fabian G, Szabo G, Nagy A, et al. Stress and Salivary Glands. Curr Pharm Des. 2017;23(27):4057-65. https://doi.or $\mathrm{g} / 10.2174 / 1381612823666170215110648$

19. Leistner C, Menke A. How to measure glucocorticoid receptor's sensitivity in patients with stress-related psychiatric disorders. Psychoneuroendocrinol. 2018; (91):235-260. https://doi.org/10.1016/j.psyneuen.2018.01.023

20. Uttra AM, Hasan U, Uttra MM, Uttra MGM. Impact of stress on various organ systems and its therapeutic management. PJMD [Internet]. 2019 [cited 2020 Jun 09];8(01):54-62. Available from: http://ojs.zu.edu.pk/ojs/index.php/pjmd/article/view/126

21. Decat CS, Laros JA, Araujo TCCF. Termômetro de Distress: validação de um instrumento breve para avaliação diagnóstica de pacientes oncológicos Psico-USF. 2009;14(3). https://doi.org/10.1590/S1413-82712009000300002

22. Instituto Nacional de Câncer (Brasil). Estimativa 2020. Incidência do Câncer no Brasil. Rio de Janeiro: INCA, 2019.

23. Vrinten C, Boniface D, Lo SH, Kobayashi LC, von Wagner C, Waller J. Does psychosocial stress exacerbate avoidant responses to cancer information in those who are afraid of cancer? a population-based survey among older adults in England. Psychol Health. 2018;33(1):117-29. https://doi.org/10.1080/08870446.2017.1314475

24. Moreno-Smith M, Lutgendorf SK, Sood AK. Impact of stress on cancer metastasis. Future Oncol. 2010;6(12):1863-81. https://doi. org/10.2217/fon. 10.142

25. Vizcaino M, Huberty J, Larkey L, Kosiorek H, Gowin K, Eckert R, et al. Dysregulation in cortisol diurnal activity among myeloproliferative neoplasms cancer patients. Hematol Med Oncol. 2018;3. doi:10.15761/HMO.1000167

26. Matoso LML, Oliveira AMB. O efeito da música na saúde humana: base de evidências científicas. Rev Cienc Desenv. 2017;10(2):76-98. https://doi.org/10.11602/1984-4271.2017.10.2.1

27. Firmeza MA, Rodrigues AB, Melo GAA, Aguiar MIF, Cunha GH, Oliveira PP, et al. Control of anxiety through music in a head and neck outpatient clinic: a randomized clinical trial. Rev Esc Enferm USP. 2017;51:e03201. https://doi.org/רᄀ10.1590/S1980-220X2016030503201

28. Taets GGCC, Borba-Pinheiro CJ, Figueiredo NMA, Dantas EHM. Impacto de um programa de musicoterapia sobre o nível de estresse de profissionais de saúde. Rev Bras Enferm. 2013;66(3):385-90. https://doi.org/ᄀᄀ10.1590/S0034-71672013000300013

29. Bergold LB, Alvim NAT. Therapeutic music as a technology applied to healthcare and to the nursing teaching. Esc Anna Nery. 2009;13(3):53742. https://doi.org/10.1590/S1414-81452009000300012 